\title{
50 LAT „ZAGADNIEŃ INFORMACJI NAUKOWEJ” (1962-2012)
}

\author{
Anna Stanis \\ Biblioteka Uniwersytecka w Warszawie
}

Czasopisma naukowe, informacja naukowa, „Zagadnienia Informacji Naukowej”, "Biuletyn Ośrodka Dokumentacji i Informacji Naukowej PAN"

Wszelkie jubileusze czy rocznice sprzyjają chęciom opisania historii danego wydarzenia, podsumowaniom, ocenom, refleksjom. Rok 2012 jest rokiem jubileuszowym powstania czasopisma „Zagadnienia Informacji Naukowej” (ZIN), które w tym roku obchodzi 50-lecie istnienia na rynku wydawniczym. $Z$ tej okazji ukazuje się zeszyt jubileuszowy i ten artykuł, w którym chciałabym opisać historię czasopisma i jego charakterystykę - materiał, który może w przyszłości zainspiruje innych autorów do głębszej analizy zawartości czasopisma i jego wpływu na środowisko bibliotekarskie.

Czasopismo „Zagadnienia Informacji Naukowej” jest kontynuacją ukazującego się w latach 1962-1971 „Biuletynu Ośrodka Dokumentacji i Informacji Naukowej PAN" (od 1975 r. Ośrodek Informacji Naukowej PAN). Od 1972 r. półrocznik ten wydawany jest pod obecnym tytułem, do 1993 r. przez Ośrodek Informacji Naukowej Polskiej Akademii Nauk, a po likwidacji tej instytucji, od 1994 r., przez Instytut Bibliotekoznawstwa i Informacji Naukowej Uniwersytetu Warszawskiego (od 1997 r. Instytut Informacji Naukowej i Studiów Bibliologicznych) oraz Stowarzyszenie Bibliotekarzy Polskich.

W życiu czasopisma można wyróżnić trzy etapy jego rozwoju:

1) Biuletyn ODilN PAN 1962-1971,

2) ZIN 1972-1993,

3) ZIN 1994-2012.

Pierwszy etap i pierwszy numer z kolejnego etapu życia czasopisma opisano w układzie chronologicznym, który pozwala obserwować zmiany zachodzące w charakterze czasopisma: wypracowywaną formę i układ, zakres tematyczny, zmiany personalne $\mathrm{w}$ redakcji. 


\section{Biuletyn Ośrodka Dokumentacji i Informacji Naukowej PAN (1962-1971)}

Pierwszy numer Biuletynu ODiIN PAN ukazał się w roku 1962 r. w Warszawie staraniem Ośrodka Dokumentacji i Informacji Naukowej PAN (Warszawa, ul. Nowy Świat 72), wydrukowany przez Warszawską Drukarnię Naukowa.

Zawiera dwie części: Część Problemową i Część Informacyjną, poprzedzone tekstem Od redakcji, w którym opisano zadania czasopisma: „Wydaniem pierwszego numeru Biuletynu Ośrodek Dokumentacji i Informacji Naukowej PAN rozpoczyna stałe informowanie placówek naukowych Polskiej Akademii Nauk o aktualnych zagadnieniach dokumentacji i informacji naukowej [...]. Zadaniem Biuletynu jest przede wszystkim publikowanie materiałów potrzebnych pracownikom służby informacyjnej placówek naukowych Polskiej Akademii Nauk do bieżącego wykonywania swych zadań, oraz doskonalenia pracy"1.

Biuletyn zaplanowano jako wydawnictwo ciagłe, ukazujące się w miarę zbierania materiałów. W 1962 r. ukazał się jeden numer czasopisma, w latach 19631971 po 2 numery, tym samym czasopismo przyjęło częstotliwość półrocznika.

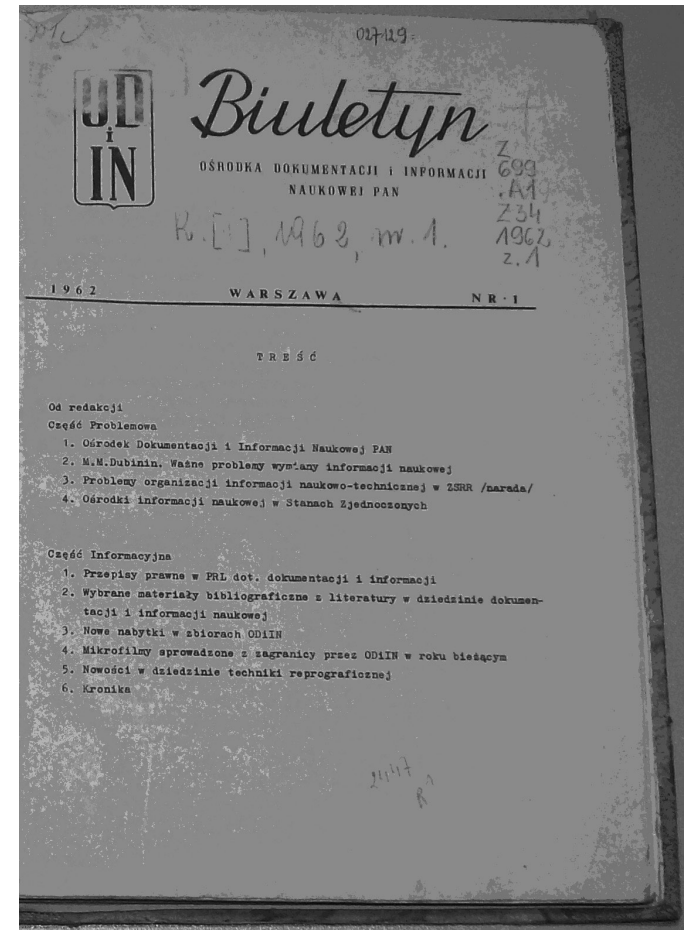

Zdjęcie pierwszego numeru „Biuletynu” 1962

W pierwszym numerze zaplanowano strukturę składającą się z trzech części:

części problemowej, zawierającej oryginalne prace z dziedziny informacji naukowej polskich autorów oraz łłumaczenia wybranych artykułów z czasopism zagranicznych;

\footnotetext{
1 „Biuletyn Ośrodka Dokumentacji i Informacji Naukowej PAN” 1962, R. [1], nr 1, s. 3.
} 
części informacyjnej, zawierającej omówienie przepisów prawnych związanych z informacja i dokumentacja, informacje bibliograficzne, informacje o nabytkach Ośrodka, informacje o nowych technikach reprograficznych, informacje o osiagnięciach naukowych placówek PAN publikowane w celu wymiany doświadczeń pomiędzy ośrodkami;

kroniki, rejestrującej aktualne wydarzenia w Polsce i za granica dotyczące informacji naukowej i dokumentacji, takie jak powstanie i działalność różnych instytucji związanych z dziedziną informacji naukowej, oraz informującej o nowych publikacjach, szczególnie zagranicznych.

Czasopismo wydawano w jednakowej szacie graficznej w formacie A5, uzupełniając je od pierwszego egzemplarza rysunkami i ilustracjami. Artykuły nie zawierały streszczeń.

Pierwszy artykuł poświęcono Ośrodkowi Dokumentacji i Informacji Naukowej PAN.

W tym samym numerze ukazały się obok siebie artykuły Problemy organizacji informacji naukowo-technicznej w ZSRR oraz Ośrodki Informacji Naukowej w Stanach Zjednoczonych. Umieszczono także retrospektywny spis przepisów prawnych dotyczących dokumentacji i informacji naukowej.

W Wybranych materiałach bibliograficznych umieszczono opisy bibliograficzne i abstrakty wybranych artykułów prasy zagranicznej, opisy bibliograficzne wybranych artykułów z prasy zagranicznej bez abstraktów i opisy książek zagranicznych.

W części informacyjnej znajduje się wykaz Nabytki Działu Zbiorów ODilN w okresie od stycznia do maja br. [1962] w układzie według rodzajów dokumentów. Zamieszczono także informacje o nowościach w dziedzinie techniki reprograficznej.

W Kronice m.in. ukazał się tekst Informacja naukowa w Japonii. Cały materiał uzupełniono różnego rodzaju komunikatami np. Notatka w sprawie składania sprawozdań z wyjazdów zagranicznych (dla pracowników PAN).

Numer jest bardzo starannie przygotowany, z dbałością o redakcję techniczną. W pierwszym numerze nie podano składu redakcji.

Opis pierwszego numeru jest dokładny, ponieważ określa te cechy periodyku, które zapoczątkowały kształt czasopisma i miały wpływ na jego dalszy rozwój, a przede wszystkim na formę i zawartość przyszłych „Zagadnień Informacji Naukowej". W kolejnych rocznikach odnotowano tylko zmiany w stosunku do poprzednich.

\section{Rocznik 1963}

W drugim numerze tego rocznika po raz pierwszy podano skład Komitetu Redakcyjnego Wydawnictw ODiIN PAN. W skład Komitetu wchodzili: Stanisław Dryl, Jadwiga Groszyńska (sekretarz), Tadeusz Jabłoński, Karol Leśniak, Józef Skrzypek, Adam Wysocki. Od drugiego numeru redakcja zrezygnowała z zamieszczania materiałów bibliograficznych zagadnień z dziedziny dokumentacji i informacji naukowej (wychodząc z założenia, że działy takie prowadza m.in. „Przegląd Piśmiennictwa o Książce”, „Przegląd Piśmiennictwa Zagadnień 
Informacji"), a także wykazu nabytków ODilN PAN (wykaz nabytków będzie ukazywał się kwartalnie jako samodzielne wydawnictwo). Zachowano podział treści czasopisma na części: problemowa, informacyjną i kronikę, choć nie zostały wyróżnione graficznie. Pierwszy numer tego rocznika zawiera ilustracje (fotografie) sprzętu do kopiowania dokumentów.

\section{Roczniki 1964 i 1965}

Stopniowo zwiększa się liczba artykułów problemowych, od 3 do 5. Od zeszytu drugiego rocznika 1964 wyodrębniono graficznie dział Recenzje i omówienia. Nie zmienił się skład redakcyjny. Redaktorem naczelnym został Kazimierz Leski. Od pierwszego numeru z tego rocznika każdy artykuł problemowy uzupełniono o streszczenie w języku polskim.

Układ kompozycyjny czasopisma utrwalił się: część problemowa (artykuły), część informacyjna (dotyczy ODilN PAN i innych placówek PAN) - zaliczyć tu można także recenzje i omówienia, ważniejsze przepisy prawne dotyczące dokumentacji i informacji naukowej, technicznej i ekonomicznej, trzecią część stanowi Kronika. Każdy artykuł redagowany jest według ustalonego schematu: imię, nazwisko autora i jego miejsce pracy, tytuł artykułu, streszczenie w języku polskim. Wzbogacono aparat pomocniczy, często do artykułów podaje się obszerne bibliografie i przypisy. Drugi numer w roczniku 1965 poświęcony jest w większości Międzynarodowemu Sympozjum zorganizowanemu w ramach państw RWPG na temat mechanizacji i automatyzacji procesów opracowywania, wyszukiwania i przekazywania informacji na odległość oraz wystawie „Inforga 65 ". Materiał z seminarium jest bogato ilustrowany.

\section{Roczniki 1966, 1967, 1968}

Liczba artykułów problemowych wzrosła od 4 do 10. Nie zmienia się struktura czasopisma. Numery zawierają liczne tablice i ilustracje.

\section{Roczniki 1969, 1970 i 1971}

Od pierwszego numeru rocznika 1969 wprowadzono dodatkowo spis treści i streszczenia artykułów w języku angielskim na końcu artykułu. Artykuły opracowywano jednolicie, według schematu: imię, nazwisko autora i jego miejsce pracy, tytuł artykułu, streszczenie w języku polskim umieszczone pod tytułem artykułu, tekst artykułu, streszczenie w języku angielskim. Rocznik 1971 jest ostatnim zatytułowanym „Biuletyn Ośrodka Dokumentacji i Informacji Naukowej PAN".

W latach 1962-1971 w 10 rocznikach łącznie ukazało się 19 numerów. Wypracowana kompozycja czasopisma obejmowała - część problemowa - oryginalne prace $z$ dziedziny informacji naukowej, tłumaczenia artykułów z języków obcych; część informacyjną - omówienie podstawowych przepisów 
prawnych dotyczących dokumentacji i informacji naukowej, wybrane informacje bibliograficzne, nabytki działu zbiorów ośrodka, nowości techniki reprograficznej oraz kronikę. Zaprezentowano ponad 100 artykułów problemowych. Aktualna tematyka, wysoki poziom opracowań, staranne wydanie wpłynęły na pozytywna opinię środowiska o tym periodyku. Uwzględniając wszystkie artykuły, recenzje, doniesienia, streszczenia oraz notatki z kroniki, obszar tematyczny „Biuletynu...” przedstawia się następująco (tabela 1):2

Tabela 1

\begin{tabular}{|c|c|c|c|c|}
\hline Lp. & Tematyka & $\begin{array}{c}\text { Art. } \\
\text { problemowe }\end{array}$ & Inne & Liczba \\
\hline 1. & $\begin{array}{l}\text { Współpraca międzynarodowa w zakresie informacji } \\
\text { naukowej }\end{array}$ & 14 & 33 & 47 \\
\hline 2. & $\begin{array}{l}\text { Informacja naukowa: } \\
- \text { w Polsce } \\
\text { - w innych krajach }\end{array}$ & $\begin{array}{l}29 \\
21\end{array}$ & $\begin{array}{l}15 \\
13\end{array}$ & $\begin{array}{l}44 \\
34\end{array}$ \\
\hline 3. & Źródła informacji & 13 & 29 & 42 \\
\hline 4. & Działalność ODilN PAN & 8 & 21 & 29 \\
\hline 5. & Szkolenie pracowników informacji naukowej & 10 & 17 & 27 \\
\hline 6. & Mechanizacja i automatyzacja procesów informacji & 9 & 13 & 22 \\
\hline 7. & $\begin{array}{l}\text { Zagadnienia ogólne informacji naukowej } \\
\text { i dokumentacji }\end{array}$ & 9 & 7 & 16 \\
\hline 8. & Reprografia & 5 & 10 & 15 \\
\hline 9. & Systemy informacyjno-wyszukiwawcze & 2 & 8 & 10 \\
\hline 10. & Potrzeby użytkowników informacji & 7 & 2 & 9 \\
\hline 11. & Metodyka prac dokumentacyjno-informacyjnych & 7 & 1 & 8 \\
\hline 12. & Klasyfikacja i indeksowanie dokumentów & 6 & 2 & 8 \\
\hline 13. & Tezaurusy & 4 & 3 & 7 \\
\hline & Razem & 144 & 174 & 318 \\
\hline
\end{tabular}

Z przedstawionego materiału wynika, iż najwięcej materiału ukazywało się na temat współpracy międzynarodowej, głównie prowadzonej w ramach RWPG. Dużą część materiału poświęcono organizacji informacji naukowej w Polsce i na świecie, a także osobno działalności ODiIN PAN. Dużą uwagę przywiązywano do źródeł informacji, co niewątpliwie miało związek z szybko rozwijającymi się wtedy dziedzinowymi systemami informacji. Dominował także zawsze aktualny temat szkolenia pracowników informacji naukowej oraz nowe technologie w mechanizacji i automatyzacji procesów informacyjnych.

W poszczególnych rocznikach nie było informacji o recenzentach, nazwiska autorów, specjalistów w swojej dziedzinie, gwarantowały wysoki poziom czasopisma. Autorami artykułów w większości byli pracownicy ODilN, ale współpracowali z czasopismem również Barbara Dziadkiewicz, Maria Dembowska, Henryk Adler, Halina Górniakowa, Krystyna Remerowa, Hanna Zasadowa, Irena Morsztynkiewiczowa, Zbigniew Żmigrodzki.

2 Tabelę opracowano na podstawie Bibliografii zawartości „Biuletynu Ośrodka Dokumentacji i Informacji Naukowej PAN” za lata 1962-1971. „Zagadnienia Informacji Naukowej" 1972, R. [10], nr 1 (20), s. 123-167. 
Nakład „Biuletynu...” w latach 1962-1971 utrzymywał się na tym samym poziomie $(300+25$ egzemplarzy), z wyjątkiem pierwszych dwóch numerów (200 i 250 egzemplarzy). Czasopismo oznaczono numerem ISSN 0030 - 6282.

\section{Zagadnienia Informacji Naukowej (1972-1993)}

Drugi etap w życiu czasopisma zamknęłabym w latach 1972-1993. Pierwszy numer „Zagadnień Informacji Naukowej”, kontynuacji wydawnictwa Ośrodka Dokumentacji i Informacji Naukowej PAN „Biuletyn Ośrodka Dokumentacji i Informacji Naukowej PAN" ukazał się w 1972, jako kolejny, 20 numer periodyku.

\section{Rocznik 1972}

Jako pierwszy pod zmienionym tytułem zawierał jeden numer, o nakładzie 525 egz. Instytucja sprawcza pozostał ODilN PAN. Numer, jako kontynuacja Biuletynu, zachował zasadniczy układ czasopisma: część problemowa (artykuły), część informacyjną (recenzje i omówienia, w tym ważniejsze przepisy prawne), kronikę, zachował też zakres tematyczny i częstotliwość.

Dorobek Biuletynu za lata 1962-1971 zawarto w bibliografii: Bibliografia zawartości „Biuletynu Ośrodka Dokumentacji i Informacji Naukowej PAN” za lata $1962-1971^{3}$ w opracowaniu Krystyny Gąsowskiej. Uwzględnia ona artykuły, recenzje, noty z kroniki, bez rubryki Ważniejsze przepisy prawne dotyczące dokumentacji i informacji naukowej, technicznej i ekonomicznej oraz bez działu Wybrane materiały bibliograficzne. Układ bibliografii jest dwustopniowy, w obrębie działów i poddziałów zastosowano układ alfabetyczny. Bibliografia zawiera pełny przegląd opublikowanych w Biuletynie materiałów i obejmuje 318 pozycji bibliograficznych. Bibliografię uzupełniono indeksem osobowym (i kryptonimów) oraz indeksem przedmiotowym. We wstępie Od Redakcji opisano zamierzenia programowe:

Redakcja „Zagadnień Informacji Naukowej” stawia sobie za cel naświetlanie najważniejszych problemów informacji naukowej w świecie i kraju, tak obecnej jak i perspektywicznej, oraz popularyzowanie zagadnień informacji poprzez publikowanie prac czołowych teoretyków informacji i jej organizatorów, zarówno polskich, jak i obcych. W czasopiśmie zamieszczane będą artykuły problemowe, omówienia syntetyzujące, przeglądy analityczne, recenzje, ważniejsze wyselekcjonowane informacje. Zamiarem naszym jest przede wszystkim propagowanie na łamach „Zagadnień Informacji Naukowej” nowych myśli, koncepcji i rozwiązań, umożliwianie konfrontacji różnych poglądów. Tematykę tę prezentować będziemy zarówno od strony teoretycznej jak i rozwiązań praktycznych. Naświetlać będziemy problemy filozofii informacji naukowej, jej teorii i systemów, zagadnienia podstaw metodycznych i środków technicznych informacji w skali jednostek organizacyjnych, systemów małych i wielkich, a ponadto aspekty formalne, społeczne i ekonomiczne informacji na wszystkich

${ }^{3}$ Bibliografia zawartości „Biuletynu Ośrodka Dokumentacji i Informacji Naukowej PAN” za lata 1962-1971. „Zagadnienia Informacji Naukowej” 1972, R. [10], nr 1 (20), s. 123-167. 
szczeblach: zakładów, pracowni, ośrodków informacji, bibliotek, archiwów itp. wszędzie tam gdzie informacja ta powstaje, jest gromadzona i przetwarzana"4.

W powyższym wstępie zaprezentowano również nowy skład Komitetu Redakcyjnego:

„Decyzją Sekretarza Naukowego Polskiej Akademii Nauk nr 78/72 z dnia 18.05.1972 r. został powołany Komitet Redakcyjny w składzie: Kazimierz Leski (redaktor naczelny), Maria Szomańska (sekretarz redakcji), Janusz Albin, Jan Fajęcki, Alina Golińska, Zdzisław Pawlak, Jerzy Pelc, Olgierd Wojtasiewicz, Krystyna Wyczańska, który będzie czuwał nad realizacją przedstawionych powyżej założeń."

Nowościa jest wprowadzenie od pierwszego numeru tego rocznika streszczeń również w języku rosyjskim. Artykuły opracowywano jednolicie, według schematu: imię, nazwisko autora i jego miejsce pracy, tytuł artykułu, streszczenie w języku polskim umieszczone pod tytułem artykułu, tekst artykułu, streszczenie w języku angielskim, streszczenie w języku rosyjskim. Materiał ilustracyjny to głównie rysunki w artykułach.

\section{Instytucje sprawcze}

Instytucja sprawczą dla czasopisma w latach 1972-1974 w dalszym ciagu pozostawał Ośrodek Dokumentacji i Informacji Naukowej PAN ( w latach 19751994 Ośrodek Informacji Naukowej PAN).

Czasopismo było drukowane w: Zakładzie Narodowym imienia Ossolińskich. Wydawnictwo Polskiej Akademii Nauk. Druk Wrocławska Drukarnia Naukowa; Zakładzie Graficznym Wydawnictw Naukowych w Łodzi; Zakładzie Graficznym Politechniki Wrocławskiej; Drukarni Uniwersytetu Wrocławskiego.

\section{Komitet Redakcyjny}

Redaktorzy naczelni: Kazimierz Leski (1972-1974), Bronisław Ługowski (1975-1992), Bożenna Bojar (1992-).

Sekretarze: Maria Szomańska (1972-1988), Anna Leśniewicz (1988-1993).

Od 1992 r. nastapiły zmiany w składzie Rady Redakcyjnej. Redaktorem naczelnym została Bożenna Bojar (w Komitecie Redakcyjnym od roku 1978), profesor Uniwersytetu Warszawskiego, która przez następnych 20 lat wyznacza kierunki rozwoju czasopisma. Jest to więc również i Jej Jubileusz 20-lecia pracy redaktora merytorycznego „Zagadnień Informacji Naukowej”.

W skład Rady weszli: Ewa Chmielewska-Gorczyca, Alina Golińska, Andrzej Gromek, Bronisław Ługowski, Mieczysław Muraszkiewicz, Hanna Popowska, Jadwiga Sadowska, Henryk Szarski, Maria Szomańska.

W latach 1972-1993 (w różnych okresach) w skład Komitetu Redakcyjnego wchodzili Janusz Ŝach, Mieczysław Derentowicz, Barbara Krygier, Hanna Uniejowska, Olgierd Wojtasiewicz, Krystyna Wyczańska, Zdzisław Bobiatyński, Władysław M. Grabski, Juliusz L. Kulikowski, Małgorzata Kłossowska, Elżbieta Malinowska.

\footnotetext{
${ }^{4}$ „Zagadnienia Informacji Naukowej” 1972, R. [10], nr 1 (20), s. 6.
} 


\section{Autorzy}

Autorzy artykułów to w większości pracownicy ODiIN (OIN) PAN i autorzy zagraniczni tłumaczeni na język polski (w dużej części reprezentujący Wszechzwiazkowy Instytut Informacji Naukowej i Technicznej (WINITI) Akademii Nauk ZSRR). W tym okresie współpracowali również z czasopismem: Witold Marciszewski, Maria Czujowa, Wanda Pindlowa, Stanisław Zadrożny, Tadeusz Wójcik, Zdzisław Słomiński, Maria Załęska, Helena Wagnerowa, Juliusz Lech Kulikowski i inni.

\section{Układ czasopisma i tematyka}

Zawartość czasopisma została podzielona na następujące działy: artykuły problemowe, materiały i przyczynki, recenzje i omówienia, kronika.

Redakcja ZIN zwróciła się z prośbą do placówek informacji naukowej o nadsyłanie materiałów o działalności informacyjnej, które zobowiązała się prezentować w kolejnych numerach, realizując konsekwentnie zamierzenia umieszczania na łamach swojego czasopisma zarówno teoretycznych, jak i praktycznych zagadnień informacji naukowej. Od 2 numeru rocznika 1982 w dziale Recenzje i omówienia redakcja rozpoczęła cykl prezentacji wybranych prac doktorskich z zakresu informacji naukowej publikowanych i niepublikowanych, opracowanych w różnych ośrodkach naukowych w kraju. Dołączono informację o dacie wpływu artykułu do redakcji (w późniejszym okresie z tej informacji zrezygnowano). Dodano wskazówki dla autorów zawierające zasady opracowywania nadesłanych materiałów. Od 2 numeru rocznika 1993 zrezygnowano ze spisu treści i streszczeń w języku rosyjskim.

Bardzo szczegółowej charakterystyki problematyki prezentowanej na łamach czasopisma w latach 1962-1977 dokonała Krystyna Wyczańska5: „Od zagadnień małej mechanizacji, uściślenia granic rodzącej się dyscypliny, jej terminologii (najpierw dokumentacji, następnie informacji naukowej, obecnie może informatologii?) przeszło pismo ku związkom z badaniami systemowymi."

Opierając się na Bibliografii zawartości „Zagadnień Informacji Naukowej” za lata 1962-1976 autorka wskazała artykuły problemowe poświęcone informacji naukowej traktowanej generalnie (107 ze 176 pozycji bibliograficznych) oraz informacji naukowej w poszczególnych dziedzinach takich jak: nauki społeczne (22 pozycje), techniczne (14 pozycji), biologiczne (10 pozycji), rolne (9 pozycji), chemiczne i fizyczne (9 pozycji), medyczne (5 pozycji). Wyodrębniła również grupę tematyczna, jaką stanowią języki informacyjno-wyszukiwawcze, tezaurusy i ich budowa, indeksowanie, klasyfikowanie. Zaznaczyła także fakt poruszania na łamach czasopisma tematów z zakresu bibliotekarstwa. W artykułach na ten temat przede wszystkim omawiano problemy bibliotek szkół wyższych i akademii nauk, problem specjalizacji i współpracy bibliotek, a także biblioteczna działalność informacyjną. Wiele artykułów i doniesień przyniosły zorganizowane

${ }^{5}$ K. Wyczańska: Przegląd problematyki zawartej $w$ „Zagadnieniach Informacji Naukowej OIN PAN” [1962-1977]. „Rocznik Biblioteki Narodowej” 1980, [druk 1981], T. 16, s. 384-388. 
przez ODilN w 1967 r. badania nad potrzebami informacyjnymi użytkowników w ośrodkach informacji PAN. Nieco mniej artykułów poświęcono kształceniom służb informacyjnych i programom nauczania na wyższych uczelniach oraz problemowi teorii tekstu. Charakter ZIN Krystyna Wyczańska określiła jako „pismo teoretyczno-informacyjne o zadaniach instruktażowych, zajmujące się przekazem treści z literatury światowej. Celem pisma jest informowanie czytelników o przemianach zachodzących w organizacji i rozwoju nauki, a w szczególności dziedziny ułatwiającej jej transmisję, jaką jest informacja naukowa"6.

W tym samym przedziale czasowym, który wyodrębniłam w historii rozwoju czasopisma (1972-1993), mieści się część charakterystyki ZIN zaprezentowana przez Zdzisława Gębołysia na łamach „Bibliotekarza”" Odnotował on, że „[...] redakcja nie odstapiła od wyrażonego w nr. 1/1972 zamiaru przedstawiania na łamach czasopisma tak teoretycznych, jak i praktycznych zagadnień informacji naukowej, starając się jednocześnie reagować na zmiany zachodzące w swojej dyscyplinie [...] ograniczę się tylko do wyliczenia najważniejszych bloków tematycznych z ostatnich 15 lat [1978-1993]: języki informacyjno-wyszukiwawcze, systemy informacyjne, informacja naukowa w różnych dziedzinach wiedzy, katalogowanie przedmiotowe [1983-1993], automatyzacja procesów biblioteczno-informacyjnych [1983-1993]".

\section{Bibliografia}

Prześledzenie tendencji rozwojowych ZIN ułatwia fakt opublikowania aż ośmiu bibliografii zawartości czasopisma (osobny wykaz bibliografii na końcu artykułu). W omawianym okresie ukazało się pięć bibliografii. Pierwszą bibliografię w historii ZIN omówiono w części Rocznik 1972 artykułu. Bibliografie starano się opracowywać według tych samych zasad, tak aby następna była zawsze kontynuacja poprzedniej.

Kolejna ukazała się w numerze pierwszym rocznika 1978: Bibliografia zawartości „Zagadnień Informacji Naukowej” za lata 1962-1977 w opracowaniu Krystyny Gasowskiej i Marii Szomańskiej. Zawiera również pozycje odnotowane w poprzedniej bibliografii. W bibliografii zachowano przyjęty w „Zagadnieniach Informacji Naukowej" podział na: Artykuły problemowe, Materiały i przyczynki, Recenzje i omówienia, Kronika oraz dodano dział Materiały bibliograficzne, do którego włączono „Ważniejsze przepisy prawne dotyczące dokumentacji i informacji naukowej, technicznej i ekonomicznej”. W poszczególnych działach pozycje bibliograficzne ułożono alfabetycznie według nazwisk autorów lub tytułów opracowań. Bibliografię uzupełniaja dwa indeksy: przedmiotowy i autorów. Indeks autorów zawiera nazwiska i imiona autorów prac oryginalnych, prac recenzowanych, autorów recenzji, komunikatów, a także autorów przekładów.

Indeks przedmiotowy zawiera hasła wynikające z treści artykułów w podziale trzystopniowym, z systemem odsyłaczy. Bibliografia obejmuje 521 pozycji.

${ }^{6}$ Ibidem.

7 Z. Gębołyś: Zagadnienia Informacji Naukowej 1994 nr 1-2 - 1995 nr 1-2. [Recenzja]. „Bibliotekarz” 1996, nr 12, s. 28-29. 
Następna bibliografia ukazała się w numerze 1 rocznika 1982: Bibliografia zawartości ZIN za lata 1978-1982 w opracowaniu Marii Szomańskiej. W bibliografii zachowano przyjęty poprzednio układ i indeksy. Działy Artykuły problemowe oraz Materiały i przyczynki zostały opracowane $w$ formie bibliografii adnotowanej. Poza opisem bibliograficznym każda pozycja zawiera krótkie streszczenie artykułu. Bibliografię ze względów praktycznych wydrukowano jednostronnie. Dział Recenzje i omówienia zawiera alfabetyczny wykaz prac autorów obcych i polskich, które były omawiane na łamach czasopisma. Dział Kronika zawiera informacje i sprawozdania z konferencji naukowych, sympozjów, seminariów i innych spotkań poświęconych informacji naukowej. Do bibliografii dołączono Wykaz skrótów. Bibliografia zawiera 117 pozycji.

Czwarta bibliografia ukazała się w numerze 1 rocznika 1987: Bibliografia zawartości „Zagadnień Informacji Naukowej” za lata 1982-1987 w opracowaniu Marii Szomańskiej. Bibliografię opracowano zgodnie z tymi samymi zasadami co poprzednie. Zawierała 161 pozycji bibliograficznych.

Piąta bibliografia ukazała się w numerze 1 rocznika 1993: Bibliografia zawartości „Zagadnień Informacji Naukowej” za lata 1987-1992 w opracowaniu Anny Leśniewicz. Bibliografię opracowano według podobnych zasad jak poprzednie. Połączono w jeden ciag alfabetyczny artykuły problemowe, materiały i przyczynki, jako bibliografię adnotowana.

\section{Wspomnienia, nekrologi}

Bardzo rzadko w tym okresie na łamach czasopisma ukazywały się wspomnienia o znanych i cenionych osobach związanych z działalnością informacyjna. W wymienionym okresie ukazały się dwa wspomnienia, jedno poświęcone Olgierdowi Ungurianowi (nr 1, 1982), drugie poświęcone Hannie Uniejowskiej (nr 2, 1988)

\section{Szata graficzna, format, objętość, nakład}

W 1993 r. ukazał się pierwszy numer ZIN opracowany i wydany samodzielnie przez Ośrodek Informacji Naukowej PAN za pomoca programu Ventura Publisher. Zachowano jednolitą szatę graficzna, utrzymano format A5. Objętość czasopisma wahała się od 100 do 200 stron. Zmieniający się nakład czasopisma pokazano w tabeli 2. Za lata 1990, 1991, 1992 brak danych.

Za cezurę w dziejach czasopisma można uznać rok 1993, w którym ukazał się podwójny numer ZIN, w małym nakładzie 350 egzemplarzy. Był to ostatni numer przygotowany przez OIN PAN.

\section{Zagadnienia Informacji Naukowej (1994-2011)}

Nowy etap w rozwoju czasopisma wyznaczyła transformacja ustrojowa, w wyniku której Polska Akademia Nauk zlikwidowała swój Ośrodek Informacji 
Naukowej. Dyrektor Generalny PAN w dniu 16.06.1994 r. wyraził zgodę na przekazanie tytułu innej instytucji sprawczej. Tytuł przejęło Stowarzyszenie Bibliotekarzy Polskich wraz z Instytutem Bibliotekoznawstwa i Informacji Naukowej Uniwersytetu Warszawskiego.

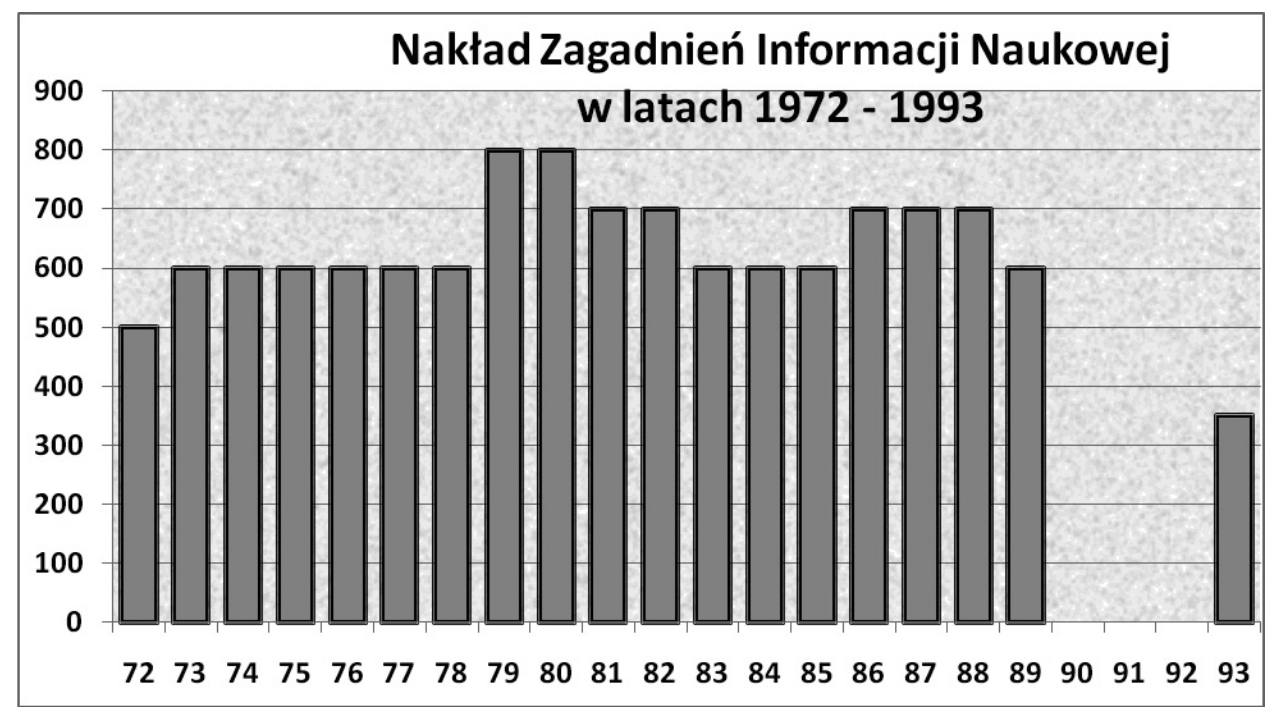

\section{Instytucje sprawcze}

Stowarzyszenie Bibliotekarzy Polskich i Instytut Bibliotekoznawstwa i Informacji Naukowej Uniwersytetu Warszawskiego (w 1997 r. zmienił nazwę na Instytut Informacji Naukowej i Studiów Bibliologicznych), to instytucje, które patronuja periodykowi do chwili obecnej. Czasopismo wydawane jest przez Wydawnictwo SBP, adres: Warszawa, Konopczyńskiego 5/7, kierowane przez 20 lat przez Janusza Nowickiego, a obecnie przez Dariusza Kozłowskiego.

Druk i oprawa: Warszawska Drukarnia Naukowa, Warszawa ul. Śniadeckich 8. Numer 2/1999 Druk: Z. P. Poligrafia ul. Smulikowskiego 6/8. Druk i oprawa od nr. 2 z 2009 r.: Zakład Poligraficzny PRIMUM s.c. Kozerki, ul. Marsa 20, Grodzisk Mazowiecki.

\section{Komitet Redakcyjny}

Redaktor naczelny: Bożenna Bojar (1992 -).

Sekretarze: Franciszek Januszkiewicz (1994), Stanisława Kurek-Kokocińska (1995-2000), Zina Jarmoszuk (2000-2009), Anna Stanis (2009-).

W 1994 r. zmienił się skład Rady Redakcyjnej: Marcin Drzewiecki (przewodniczący), Mieczysław Muraszkiewicz, Hanna Popowska, Jadwiga Sadowska, Anna Sitarska, Marta Skalska-Zlat, Barbara Sordylowa, Ewa Stępniak, Henryk Szarski, Mieczysław Szyszko, Jadwiga Woźniak, Elżbieta Barbara Zybert. Okresowo w Radzie Redakcyjnej uczestniczyli: Jan Wołosz, Ewa Barteczko, Henryk Hollender, Aleksander Radwański. 
Aktualny skład Rady Redakcyjnej jest następujący: Dariusz Kuźmina (przewodniczący od 2009 r.), Wiesław Babik, Jerzy Franke, Halina Ganińska, Anna Grzecznowska, Ewa Kobierska-Maciuszko, Stanisława Kurek-Kokocińska, Hanna Popowska, Jadwiga Sadowska, Marta Skalska-Zlat, Barbara Sosińska-Kalata, Jadwiga Woźniak-Kasperek, Elżbieta Barbara Zybert.

Każdy numer czasopisma opracowuje i przygotowuje do wydawnictwa dwuosobowy zespół redakcyjny. Redaktor naczelny Bożenna Bojar od chwili objęcia tej funkcji redaguje każdy tekst, który ukazuje się w czasopiśmie, mając tym samym ogromny wpływ na jego zawartość merytoryczna. Sprawami organizacyjnymi zajmuje się sekretarz redakcji Anna Stanis.

\section{Autorzy, recenzenci, tłumacze streszczeń}

Polityka wydawnicza czasopisma zakłada m.in. pozyskiwanie materiałów od bardzo dobrych autorów na gruncie często doraźnych kontaktów. Zgodnie z jednym z podstawowych celów sformułowanych przez władze Stowarzyszenia i ówczesnego dyrektora Instytutu prof. dr. Drzewieckiego łamy czasopisma sa otwarte również dla młodych pracowników nauki i wyróżniających się absolwentów kierunku bibliotekoznawstwo i informacja naukowa. Po przeanalizowaniu autorstwa 219 artykułów problemowych (projektowych, analitycznych, syntetycznych, opisujących wyniki badań) zamieszczonych w dziale Rozprawy, badania, materiały w latach 1994-2011 stwierdziłam, że prawie wszyscy autorzy reprezentują uczelnie i szkoły wyższe różnych typów oraz biblioteki naukowe (tylko 2 autorów związanych było z bibliotekami publicznymi). Przeważnie sa to pracownicy naukowi instytutów bibliotekoznawstwa i informacji naukowej, bibliotekarze bibliotek naukowych, przedstawiciele różnego typu środowisk naukowych związanych z działalnością informacyjna. Część autorów to absolwenci bądź studenci różnych lat studiów bibliologicznych i informacyjnych (studenci Instytutu Informacji Naukowej i Studiów Bibliologicznych Uniwersytetu Warszawskiego - 6, absolwenci tegoż Instytutu - 5; absolwenci Instytutu Informacji Naukowej i Bibliotekoznawstwa we Wrocławiu - 2; absolwent Instytutu Bibliotekoznawstwa i Informacji Naukowej w Łodzi - 1). Występowanie obok siebie artykułów opracowanych przez doświadczonych w pracy zawodowej autorów i studiujących bądź „,ẃwieżo upieczonych” absolwentów wzbogaciło treść czasopisma, dając zrównoważone spojrzenie na rozwój dyscypliny (doświadczenie a oczekiwania; sprawdzone rozwiązania a awangardowa innowacyjność).

W wymienionym okresie ukazało się 8 artykułów autorów zagranicznych. Najwięcej autorów wywodzi się ze środowiska uniwersyteckiego, a w szczególności z Uniwersytetu Warszawskiego - 36 (w tym IINiSB - 16, BUW - 7, pozostałe - 13), następnie z Uniwersytetu Jagiellońskiego - 25, Uniwersytetu Łódzkiego - 13, Uniwersytetu Wrocławskiego - 11, Uniwersytetu Śląskiego - 9, Uniwersytetu Mikołaja Kopernika w Toruniu - 8, UMCS w Lublinie - 6; Uniwersytetu w Białymstoku - 2; Uniwersytetu w Rzeszowie - 1; Uniwersytetu Warmińsko-Mazurskiego - 1.

Drugim co do wielkości środowiskiem reprezentowanym w ZIN są biblioteki naukowe, a szczególnie Biblioteka Narodowa - 16 i Biblioteka Sejmowa - 11. 
Nieco mniej licznie reprezentowane są politechniki: Politechnika Wrocławska - 5 Politechnika Świętokrzyska - 4, Politechnika Łódzka - 2, pozostałe Warszawska, Białostocka, Krakowska, Gdańska po 1.

Pozostali autorzy związani byli ze Szkołami Wyższymi Pedagogicznymi, Akademiami Medycznymi, Rolniczymi, Ekonomicznymi, Instytucjami Kultury i innymi instytucjami.

\section{Recenzenci}

Od 2000 r. czasopismo jest recenzowane przez znane w środowisku autorytety naukowe: Wiesław Babik, Małgorzata Kisilowska, Mieczysław Muraszkiewicz, Jadwiga Sadowska, Marta Skalska-Zlat, Barbara Sosińska-Kalata, Barbara Stefaniak, Jadwiga Woźniak-Kasperek, Elżbieta Barbara Zybert. Przy recenzowaniu artykułu bierze się pod uwagę, czy treść artykułu odpowiada profilowi czasopisma, czy reprezentuje aktualny stan wiedzy na dany temat, czy ujęcie tematu i wnioski są poprawne, czy był wcześniej publikowany (dopuszcza się artykuł opracowany na kanwie wcześniej wygłoszonego referatu), czy tekst ma logiczna budowę i jest poprawny pod względem stylistycznym, czy streszczenie i bibliografia sa poprawnie opracowane.

\section{Tłumacze}

Elżbieta Artowicz, Małgorzata Kisilowska, Michał Zając.

\section{Korektorzy}

W 1994 r. korektę czasopisma wykonała Jadwiga Krawczyk. Od 1995 r. do chwili obecnej korektę wykonuje, z niezwykłą precyzją, Jadwiga Krężlewicz.

\section{Układ czasopisma i tematyka}

Kompozycja wewnętrzna ZIN uległa modyfikacji, artykuły połączono z materiałami i przyczynkami tworząc dział I. Rozprawy, badania, materiały. Nie zmieniły się działy: II. Recenzje i omówienia i III. Kronika i w takiej postaci czasopismo pozostało do dnia dzisiejszego. Zaczęły się w nim ukazywać zapewne idące „z duchem czasu” materiały reklamowe wydawnictw SBP, jak również informacje dla kandydatów o studiach bibliotekoznawczych na UW, informacje o prenumeracie i sprzedaży. W latach 1995 i 1996 ukazał się wybór prac opublikowanych w tych latach przez pracowników Instytutu Bibliotekoznawstwa i Informacji Naukowej UW. Od 1998 do 2009 r. ukazywało się regularnie co roku Sprawozdanie z działalności IINiSB UW w opracowaniu sekretarza naukowego Roberta Brzóski. Autorzy otrzymali dokładne wskazówki dotyczące materiałów przygotowywanych do numeru. 
Od 1994 r. streszczenia i spisy treści występowały w języku angielskim i rosyjskim. Streszczenia w języku polskim zastapiono słowami kluczowymi. Od 1996 r. zrezygnowano ze streszczeń i spisów treści w języku rosyjskim. Od 1999 r. ustaliła się struktura artykułu: tytuł, autor i jego miejsce pracy, słowa kluczowe, artykuł, streszczenie w języku angielskim. Liczba artykułów w numerze: od 4 do 10.

Wymieniany wcześniej Zdzisław Gębołyś dokonał analizy problematyki omawianej w ZIN w odniesieniu do roczników 1994 i 1995 i stwierdził, iż problematyka ta „nie odbiega zasadniczo od wcześniejszych roczników. Obecne są teksty dotyczące języków informacyjnych, tezaurusów, baz i banków danych, systemów informacyjnych, źródeł informacji. Redakcja stara się utrzymać równowagę między teorią a praktyką informacji naukowej, czego wyrazem sa m.in. publikacje o wdrożeniach projektów np. tezaurusów w Bibliotece Sejmowej, komputerowego systemu bibliografii slawistycznej. [...] Najczęściej recenzowanymi były słowniki [słów kluczowych, języka haseł przedmiotowych BN], ale również prace z metodologii systemów i systemów biblioteczno-informacyjnych"8.

Autor podkreślił również dbałość o wysoki poziom pisma, dbałość o styl i poprawność językową zamieszczanych publikacji.

W 1997 r. ukazał się artykuł Bożenny Bojar i Stanisławy Kurek-Kokocińskiej ${ }^{9}$, w którym potwierdzono, uzupełniono i rozszerzono powyższe spostrzeżenia, $\mathrm{m}$. in. wspominając o systemie indeksowania przedmiotowego. „W artykułach opublikowanych na łamach ZIN znalazły się rozważania dotyczące tematów, określników w roli hasła przedmiotowego w opisie dokumentu czy - ogólnie mówiąc - kondycji i jakości charakterystyk wyszukiwawczych formułowanych w tym języku. Od historycznych podstawowych książek A. Łysakowskiego do czasu ukazania się odrębnych prac, np. J. Ćwiekowej i J. Sadowskiej były to jedyne publikacje z omawianego zakresu. Dziś w nurcie tematycznym pozostaja artykuły na temat kartotek wzorcowych haseł przedmiotowych. [...] Równie szeroki wkład otrzymały języki deskryptorowe, których teoria rozwinięta została w ramach takich tematów jak: struktura języka deskryptorowego, leksyka, słowniki normatywne. [...] Czasopismo wykreowało badawcze zainteresowanie sprawami języków informacyjnych, towarzyszyło powstaniu i patronowało rozwojowi tej specjalizacji".

„Zagadnieniom” udało się przez wiele lat zachować ciagłość tematyczna, nie tracąc na aktualności przekazywanych informacji. Analizując tematykę artykułów wyodrębniłam następujące grupy tematyczne:

1. Języki informacyjno-wyszukiwawcze - 39 .

Problematyka teorii i praktyki języków informacyjnych w ostatnich latach wyznaczała zasadniczy obszar merytoryczny czasopisma. ZIN jako jeden z pierwszych podejmował m.in. tematykę haseł wzorcowych ${ }^{10}$.

8 Ibidem.

${ }^{9}$ B. Bojar, S. Kurek-Kokocińska: „Zagadnienia Informacji Naukowej” wobec teoretycznych i praktycznych aspektów dyscypliny. „Przegląd biblioteczny” 1997, z. 4, s. 432-433.

$10 \mathrm{Na}$ temat języków informacyjno-wyszukiwawczych pisali m.in.: Jolanta Sobielga (nr 2/1997); Jadwiga Woźniak (nr 2/1998); Wiesław Babik, Stanisława Kurek-Kokocińska (nr 1/1999); Hanna Popowska, Teresa Głowacka (nr 2/1999); Andrzej Padziński, Barbara Kotalska (nr 1/2000); Bożenna Bojar (nr 2/2001; nr 1/2009); Danuta Patkaniowska (nr 1/2003); Małgorzata Kisilowska (nr 1/2004); Anna Stanis (nr 1/2006). 
2. Internet i publikacje elektroniczne - 34 .

W dobie szybko rozwijających się społeczeństw informacyjnych nie dziwi fakt równie dużej liczby publikacji na temat Internetu. Czasopismo reaguje na aktualne tendencje w zainteresowaniach środowiska informacyjnego ${ }^{11}$.

3. Projektowanie, tworzenie, eksploatacja i oceny efektywności systemów informacyjnych (w tym systemów bibliotecznych) - 23 .

Spośród 23 artykułów na powyższy temat 10 poświęcono systemom wyszukiwania informacji. We wcześniejszej problematyce czasopisma to języki informacyjno-wyszukiwawcze i systemy informacyjne były najbardziej obszernymi blokami tematycznymi ${ }^{12}$.

4. Bazy danych i metodyka opracowania i udostępniania danych, metadane -20 .

5. Badania użytkowników systemów informacyjnych, bibliometria - 14 .

6. Przetwarzanie wiedzy, organizacja i zarządzanie wiedzą - 13.

7. Biblioteki wirtualne, cyfrowe -10 .

8. Społeczeństwo informacyjne, komunikacja naukowa - 10.

9. Bibliotekarstwo, działalność bibliotek - 10.

10. Przetwarzanie informacji w językach naturalnych i sztucznych -6 .

11. Kształcenie w dziedzinie informacji naukowej -5 .

12. Prasa, czasopisma -4.

13. Zagadnienia normalizacji -4 .

14. Statystyka wydawnicza - 3 .

W historii tematyki ZIN utrzymała się wiodąca rola języków informacyjno-wyszukiwawczych, kolejne bloki tematyczne to zagadnienia związane z Internetem i systemy informacyjne. Prawie zniknęły zagadnienia współpracy międzynarodowej, zajmujące w początkach pisma czołową pozycję w publikacji materiałów.

W mniejszym stopniu poruszano zagadnienia: konwersji retrospektywnej, sztucznej inteligencji, szarej literatury, źródeł informacji, dokumentów audiowizualnych, bibliografii i Instytutu Bibliograficznego BN, technologii informacyjnych. W zakresie technologii informacyjnych zespół redakcyjny wypowiedział się następująco:

„Adaptacja na grunt informacji naukowej zagadnień technologicznych kusi tekstami z dziedziny komputerowego oprogramowania, sieci informacyjnych, opisu przebiegu procesu komputeryzacji, spektakularnych wyszukiwań itp. Tematy tego typu obecne sa w innych czasopismach. W ZIN świadomie zrezygnowaliśmy z publikacji o podobnym charakterze [...] rynek jest w tej mierze nasycony, zarówno w dziedzinie profesjonalnych czasopism informatycznych, jak i w zakresie publikowanych materiałów z licznych wiążących się tematycznie konferencji środowiska bibliotekarskiego"13.

Nie znalazła większego odzwierciedlenia w artykułach ZIN problematyka teorii i praktyki informacji faktograficznej, a także prawne aspekty informacji.

${ }^{11} \mathrm{Na}$ temat Internetu i publikacji elektronicznych pisali m.in.: Małgorzata Góralska (nr 2/1996); Czesław Daniłowicz (nr 1/1998); Zina Jarmoszuk (nr 1/2003); Jadwiga Woźniak-Kasperek (nr 1/2004); Marcin Roszkowski (nr 2/2005).

${ }^{12} \mathrm{Na}$ temat systemów informacyjnych pisali m.in.: Wiesław Babik (nr 1-2/1994); Barbara Wereszczyńska-Cisło (nr 1-2/1995); Maria Próchnicka (nr 1/1996); Jadwiga Woźniak-Kasperek , Anna Prożych (nr 1/1997).

${ }^{13}$ B. Bojar, S. Kurek-Kokocińska: „Zagadnienia Informacji Naukowej”..., op. cit., s. 434. 
Zawartość czasopisma jest dokumentowana, m.in., w Library and Information Science Abstracts” oraz „Knowledge Organization” (od 2000 r.).

\section{Bibliografia}

Tak jak w poprzednich numerach czasopisma systematycznie opracowywana jest bibliografia. Do 1 numeru rocznika 1999 dołączono aneks Bibliografia adnotowana Zagadnień Informacji Naukowej 1993-1999 w opracowaniu Stanisławy Kurek-Kokocińskiej, zawierająca 174 pozycje bibliograficzne. Układ według dotychczasowych zasad uzupełniony został indeksem osobowym i rzeczowym. Indeks rzeczowy wykazuje w szeregu abecadłowym nazwy własne inne niż osobowe, odwzorowujące treść indeksowanych dokumentów oraz nazwy zagadnień. Nazwy zagadnień mają postać słów kluczowych.

Kolejna bibliografia adnotowana ukazała się w 1 numerze 2005 roku: Bibliografia Zagadnień Informacji Naukowej 1999-2004 w opracowaniu Ziny Jarmoszuk, w dotychczasowym układzie, uzupełniona indeksem osobowym i rzeczowym.

Ostatnia bibliografia znajduje się w 1 numerze 2011 r.: Bibliografia „Zagadnień Informacji Naukowej" 2005-2010 w opracowaniu Anny Stanis. Sporządzono ją zgodnie ze wcześniejszymi zasadami, z indeksem osobowym i rzeczowym.

\section{Wspomnienia, nekrologi}

Olgierd Adrian Wojtasiewicz (nr 1-2, 1995).

Henryk Sawoniak (nr 1, 2003).

Eugeniusz Ścibor - opatrzone bibliografią najważniejszych prac (nr 2, 2003). Maria Dembowska (nr 2, 2008).

\section{Szata graficzna, format, objętość, nakład}

W omawianym okresie zmieniono szatę graficzna, która w swoim rozwiązaniu nawiązywała do poprzedniej okładki, zmieniono format z A5 na B5.

Przeciętna objętość numeru to około 100-150 stron.

Rocznik 2008 był dofinansowany przez Ministra Nauki i Szkolnictwa Wyższego, rocznik 2009 zrealizowano ze środków Ministra Kultury i Dziedzictwa Narodowego i dofinansowania Ministra Nauki i Szkolnictwa Wyższego.

Ze względu na nakład jest to czasopismo elitarne, przeznaczone dla wąskiego grona odbiorców, specjalistów zajmujących się zagadnieniami informacji. Nakład wahał się od 350 do 450 egzemplarzy.

Czasopismo oznaczono numerem ISSN 0324-8194. 


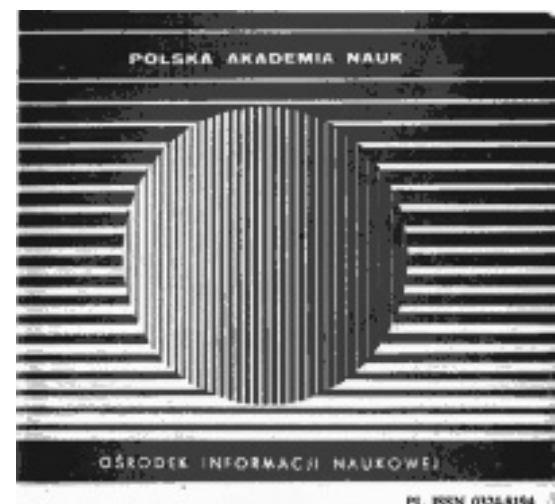

ZAGADMIENIA

INFORMACJI

HAUKOWEJ

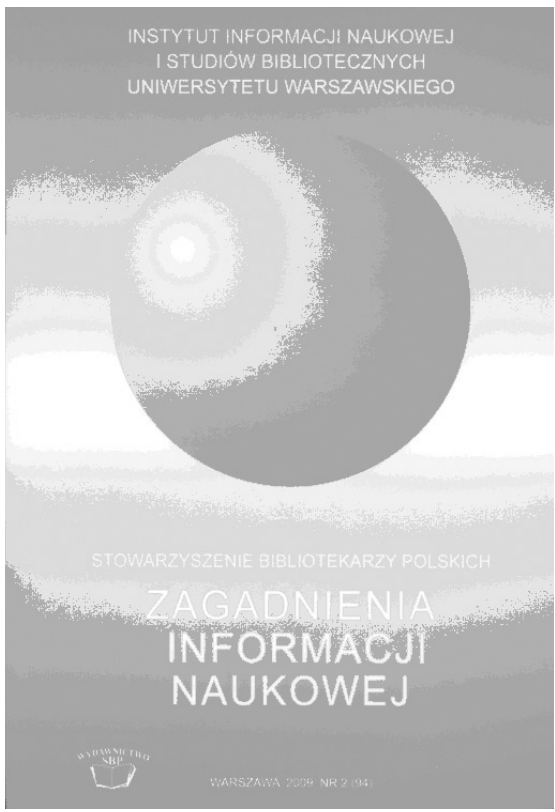

\section{Podsumowanie}

Pięćdziesiąt lat historii czasopisma potwierdza fakt, że jest ono potrzebne środowisku informacyjnemu. Staranna szata edycyjna, wysoki poziom naukowy publikowanych w nim artykułów zapewniły czasopismu stały krag odbiorców, choć ze względu na mały nakład jest to krąg elitarny. Wywodzący się od „Biuletynu" przejrzysty układ czasopisma, nieco później zmodyfikowany, zachowana ciągłość problemowa, odzwierciedlenie aktualnej problematyki badań, staranna redakcja techniczna, rzetelne i wnikliwe recenzje są niewątpliwie zaletami czasopisma.

W ZIN często ukazywały się artykuły zwiastujące przyszłe zagadnienia dyscypliny. Jako forum publikacji artykułów naukowych, można mu przypisać rolę inspirująco twórczą dla wielu pokoleń pracowników informacji i bibliotekarzy.

Obecna zawsze w czasopiśmie Kronika jest uzupełnieniem artykułów problemowych i „służy dokumentacji przejawów życia naukowego środowiska. Wybiórczo w zakresie tematów dyscypliny podstawowej i pokrewnych (bibliotekarstwo, edukacja, informatyka, nauka o komunikacji, językoznawstwo) zamieszczamy sprawozdania uczestników konferencji, narad i innych spotkań grupujących przedstawicieli środowisk zainteresowanych rozmaitymi aspektami podejścia do problemu informacji. Jako czasopismo stricte naukowe unikamy pełnego przeglądu zdarzeń, jak też anonsów, sygnałów itp. komunikatów o nikłej wartości problemowej"14.

Interesująca analizę pod względem cytowań przeprowadziła Jolanta Sobielga, która przeanalizowała następujące czasopisma: „Przegląd biblioteczny”,

${ }^{14}$ Ibidem. 
„Praktyka i teoria informacji naukowej i technicznej”, „Bibliotekarz”, „Poradnik bibliotekarza”, „Zagadnienia Informacji Naukowej”.

„Zagadnienia” charakteryzują się największym udziałem cytowań źródeł obcojęzycznych, jak również cytowań źródeł z czasopism oraz materiałów konferencyjnych. Publikacje zamieszczone w tym czasopiśmie charakteryzują się największą liczbą cytowań w pozostałych czasopismach. Podobnie każda publikacja zawarta w „Zagadnieniach” posiada największą średnią liczbę cytowań. Wśród pozostałych czasopism wyróżnia je również największy udział autorów wywodzących się ze środowisk akademickich"15.

Ostatnio w świecie dominuje tendencja ukazywania się czasopism na nośnikach papierowych w niewielkim nakładzie. Dzięki projektowi „Digitalizacja czasopism naukowych SBP", realizowanemu przez Stowarzyszenie Bibliotekarzy Polskich we współpracy z Instytutem Informacji Naukowej i Studiów Bibliologicznych UW, w ramach programu „Zasoby cyfrowe”, priorytet „Digitalizacja materiałów bibliotecznych", dofinansowanemu ze środków Ministra Kultury i Dziedzictwa Narodowego, 69 zeszytów (za lata 1972-2007) „Zagadnień Informacji Naukowej" ukazało się w wersji elektronicznej na stronie Bibliologicznej Biblioteki Cyfrowej (http://bbc.uw.edu.pl/dlibra/collectiondescription?dirids=13) w kolekcji Zagadnienia Informacji Naukowej. Dzięki temu czasopismo ma szansę na poszerzenie kręgu swoich odbiorców.

Krótka historia czasopisma, wskazówki dla autorów, spisy treści i streszczenia artykułów z poszczególnych numerów ukazują się na stronie internetowej SBP - Wydawnictwa SBP - Czasopisma SBP (http://www.sbp.pl/artykul/?ci$\mathrm{d}=2885 \&$ prev=497).

Z pewnością są tematy, które były w ZIN „mniej rozpoznane”, stosunkowo mało było listów do redakcji i polemik z autorami artykułów „ale łamy tego czasopisma sa otwarte dla wszystkich teoretyków i praktyków tej dziedziny [bibliotekoznawstwo i informacja naukowa AS]. Redakcja zachęca wszystkich czytelników do współpracy prosząc o nadsyłanie artykułów oraz uwag dotyczących ukazujących się na jego łamach publikacji”16.

Analiza artykułów zamieszczonych w ZIN to również analiza historii i aktualnych tendencji ujawniających się w rozwoju szeroko pojętej dyscypliny, jaką jest informacja naukowa.

\section{Bibliografie zawartości „Zagadnień Informacji Naukowej”:}

1. Bibliografia zawartości „Biuletynu Ośrodka Dokumentacji i Informacji Naukowej PAN” za lata 1962-1971. „Zagadnienia Informacji Naukowej”. Oprac. Krystyna Gassowska. 1972, R. [10], nr 1 (20), s. 123-167.

2. Bibliografia zawartości „Zagadnień Informacji Naukowej” za lata 1962-1977. Oprac. Krystyna Gąsowska, Maria Szomańska. „Zagadnienia Informacji Naukowej” 1978, R. [16], nr 1 (32), s. 5-164.

3. Bibliografia zawartości „Zagadnień Informacji Naukowej” za lata 1978-1982. Oprac. Maria Szomańska. „Zagadnienia Informacji Naukowej” 1982, R. [20], nr 1 (40), s. 135-187.

15 J. Sobielga: „Kto jest kim?” wśród czasopism z zakresu bibliotekoznawstwa i informacji naukowej. „Poradnik Bibliotekarza” 2002, nr 7-8 (628-629), s. 19-20.

${ }^{16}$ B. Bojar, S. Kurek-Kokocińska: „Zagadnienia Informacji Naukowej”... op. cit., s. 435. 
4. Bibliografia zawartości „Zagadnień Informacji Naukowej” za lata 1982-1987. Oprac. Maria Szomańska. „Zagadnienia Informacji Naukowej” 1987, R. [25], nr 1 (50), s. 123-187.

5. Bibliografia zawartości „Zagadnień Informacji Naukowej” za lata 1987-1992. Oprac. Anna Leśniewicz. „Zagadnienia Informacji Naukowej” 1993, R. [31], nr 1 (61), s. 163-222.

6. Bibliografia „Zagadnień Informacji Naukowej” za lata 1993-1999. Oprac. Stanisława Kurek-Kokocińska. „Zagadnienia Informacji Naukowej” 1999, R. [37], nr 1 (73), s. 84-119.

7. Bibliografia „Zagadnień Informacji Naukowej” 1999-2004. Oprac. Zina Jarmoszuk. „Zagadnienia Informacji Naukowej” 2005, R. [43], nr 1 (85), s. 115-145.

8. Bibliografia „Zagadnień Informacji Naukowej” 2005-2010. Oprac. Anna Stanis. „Zagadnienia Informacji Naukowej” 2011, R. [49], nr 1 (97), s. 80-97.

\section{Summary}

The anniversary - 50 years of publication - makes an occasion to describe the „Zagadnienia Informacji Naukowej” (ZIN) journal's history from its beginning up till now. Three stages have been selected: 1) Polish Academy of Sciences - Documentation and Information Science Centre Bulletin 19621972; 2) ZIN 1972-1993; 3) ZIN 1994-2011. The author presents the journal's composition, form, respective institutions responsible for publishing, editorial board, and thematic profile. 